Life Science 10 (1) (2021)

Life Science

http://journal.unnes.ac.id/sju/index.php/LifeSci

\title{
Keanekaragaman Jenis Burung di Kawasan Taman Wisata Alam Hutan Gambut Baning Sintang
}

\section{Harits Yowansyah Pandayu Putra, Ari Hepi Yanti ${ }^{\bowtie}$, Riyandi}

Jurusan Biologi, Fakultas Matematika dan Ilmu Pengetahuan Alam Universitas Tanjungpura Pontianak, Indonesia

\section{Info Artikel}

Diterima: 1 Maret 2021

Disetujui: 30 Maret 2021

Dipublikasikan: 15 April 2021

Keywords: diversity; bird; Baning Sintang Forest keanekaragaman; burung; Hutan Baning Sintang

\section{Abstract}

Research about bird species diversity in Nature Park of Peat Forest Baning Sintang was conducted in December 2018 to February 2019. This study aims to obtain information about bird species diversity in four types area Nature Park of Peat Forest Baning Sintang and influence of vegetation, noise levels and human activities for bird species diversity. Data collection is done by determining the point and time of observation, observation of bird diversity, vegetation, measuring environment parameters, noise levels and human activities. The results of data collection were analyzed to description analysis and PCA. The results showed 32 species of birds and 989 birds were found. The highest diversity index is the primary forest type area $\left(H^{\prime}=\right.$ 2.51) and the lowest diversity index is the residential type area $\left(H^{\prime}=0.62\right)$. Based on PCA analysis, humidity is the most influential environmental factor in primary forest, while noise is the most influential environmental factor in residential.

\begin{abstract}
Abstrak
Penelitian tentang Keanekaragaman Jenis Burung di Kawasan Taman Wisata Alam Hutan Gambut Baning Sintang telah dilakukan pada bulan Desember 2018 sampai Februari 2019. Penelitian ini bertujuan untuk mengetahui keanekaragaman jenis burung di empat tipe kawasan TWA Hutan Gambut Baning Sintang dan pengaruh vegetasi, tingkat kebisingan dan aktivitas manusia terhadap keanekaragaman jenis burung. Pengumpulan data dilakukan dengan cara menentukan titik dan waktu pengamatan, pengambilan data keanekaragaman dan kekayaan burung, vegetasi, mengukur parameter lingkungan, tingkat kebisingan dan aktivitas manusia. Hasil pengumpulan data dianalisis dan dihubungkan dengan analisis deskripsi dan PCA. Hasil yang diperoleh menunjukkan 32 jenis burung dan 989 ekor burung yang ditemukan. Indeks keanekaragaman tertinggi berada di tipe penutupan lahan hutan primer $\left(H^{\prime}=2,51\right)$ dan indeks keanekaragaman terendah berada di tipe penutupan lahan pemukiman $\left(\mathrm{H}^{\prime}=0,62\right)$. Berdasarkan analisis PCA, kelembaban adalah faktor lingkungan yang paling berpengaruh di hutan primer, sedangkan suara adalah faktor lingkungan yang paling berpengaruh di pemukiman.
\end{abstract}




\section{PENDAHULUAN}

Kawasan Taman Wisata Alam (TWA) Hutan Gambut Baning Sintang merupakan satu-satunya Ruang Terbuka Hijau (RTH) berjenis hutan kota yang ada di Kota Sintang dan memiliki fungsi ekologis. Kawasan ini memiliki luas sebesar 213 ha dari 4.128,99 ha Kota Sintang. Berdasarkan data dari Balai Konservasi Sumber Daya Alam (BKSDA) Kalimantan Barat tahun 2017, penutupan lahan di kawasan ini dibedakan menjadi empat tipe, yaitu hutan gambut primer, hutan sekunder, semak belukar dan pemukiman.

Perbedaan tipe penutupan lahan di kawasan TWA Hutan Gambut Baning Sintang membuat pola dan karakter lingkungan pada masing-masing tipe penutupan lahan berbeda. Menurut Alikodra (1990), kepadatan populasi satwaliar akan bervariasi menurut wilayah dan tipe habitat. Burung merupakan salah satu satwa liar yang menempati kawasan TWA Hutan Gambut Baning Sintang. Keberadaan burung di kawasan tersebut sangat penting karena keanekaragaman jenis burung dapat dijadikan indikator lingkungan (Ghifari et al., 2016).

Kawasan TWA Hutan Gambut Baning Sintang mengalami pergeseran fungsi ekologis akibat adanya gangguan. Letak kawasan yang berada di tengah kota dan dikelilingi pemukiman membuat TWA Hutan Gambut Baning Sintang tidak terhindarkan dari aktivitas manusia. Kurniawati (2012) mencatat bahwa pemukiman penduduk menyebar hampir di sekeliling kawasan, bahkan ada yang sudah berada di dalam kawasan. Hanya di bagian kecil area sebelah barat daya kawasan saja yang tidak terdapat pemukiman, tetapi berupa semak atau belukar.

Perubahan vegetasi di kawasan TWA Hutan Gambut Baning Sintang akibat aktivitas manusia tentu memengaruhi burung di dalamnya. Utaminingrum \& Sulistyadi (2010) juga menyatakan bahwa perubahan vegetasi dalam suatu habitat dapat mempengaruhi variasi dan jumlah kehadiran burungberdasarkan dari hasil analisis korelasi antara tipe tutupan lahan yang mengalami perubahan atau tidak terhadap burung. Beberapa penelitian menunjukkan bahwa perubahan struktur dan komposisi tumbuhan akibat pemanenan kayu merubah kelimpahan dan keragaman jenis burung (Welsh, 1987; Thompson et al., 1999). Hasil penelitian Kuswanda (2007) juga menemukan bahwa keragaman jenis burung sangat dipengaruhi oleh potensi tumbuhan yang terdapat dalam habitatnya, terutama tumbuhan yang dapat menjadi sumber pakan. Hal serupa ditemukan pula oleh Laiolo et al. (2003) yang menyatakan bahwa perubahan struktur hutan dapat mempengaruhi perubahan pemanfaatan ruang oleh burung sehingga berdampak terhadap keanekaragamannya. Penelitian ini dilakukan untuk melihat pengaruh perbedaan empat tipe penutupan lahan dan gangguan akibat aktivitas manusia terhadap keanekaragaman jenis burung di kawasan TWA Hutan Gambut Baning Sintang.

\section{METODE}

Penelitian ini dilakukan pada Bulan Desember 2018 sampai Februari 2019. Lokasi penelitian di Taman Wisata Alam Hutan Gambut Baning Sintang, Kalimantan Barat. 


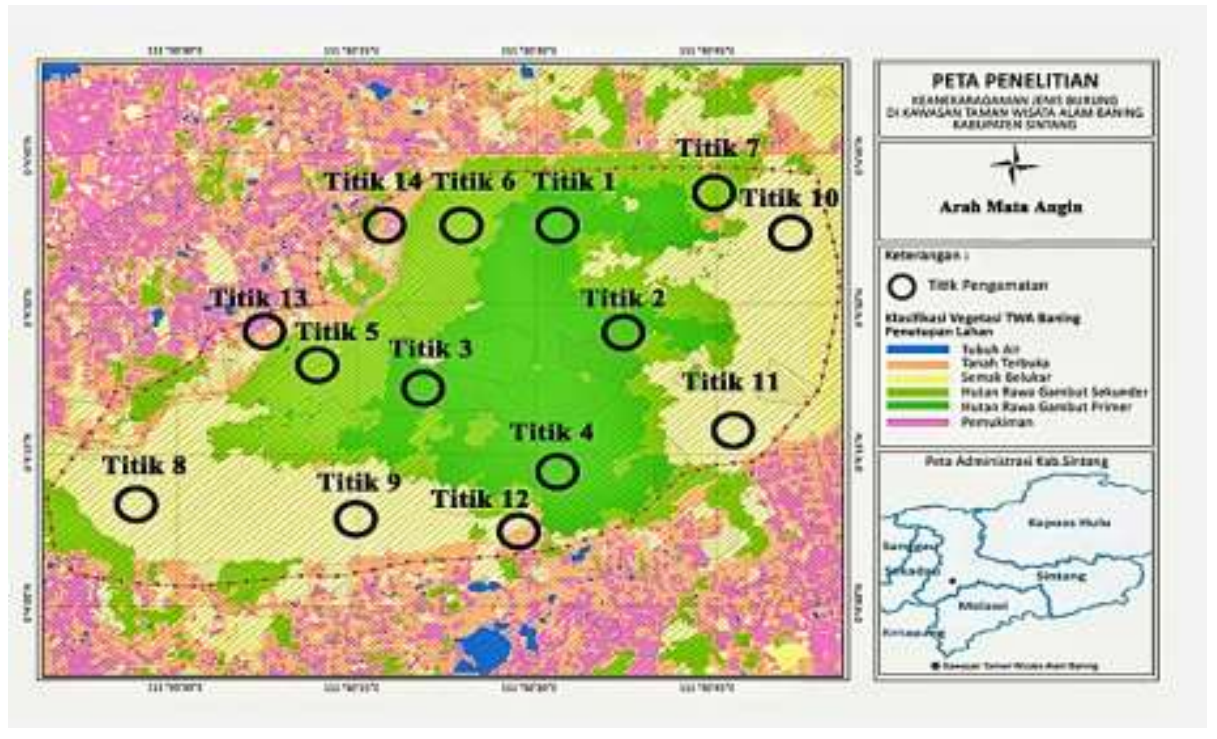

\section{Gambar 1. Peta Lokasi Penelitian}

Keanekaragaman burung diukur di beberapa titik pengamatan (Gambar 1). Penentuan titik pengamatan pada masing-masing tipe klasifikasi penutupan lahan dilakukan dengan cara purposive sampling. Total titik hitung dalam penelitian ini adalah 14 titik. Pengambilan data keanekaragaman burung pada masing-masing titik hitung diulang sebanyak tiga kali pada tiga hari yang berbeda dan tidak berturut-turut. Pengambilan data keanekaragaman burung pada masing-masing titik dilakukan dalam selang waktu pukul 05.00 - 09.00 WIB dan pukul 14.00 - 18.00 WIB. Rentang waktu pengamatan dilakukan selama 20 menit. 10 menit untuk pengamatan di setiap titik dan 10 menit untuk waktu berjalan ke titik pengamatan selanjutnya (Moen, 1973; Alikodra, 1990).

Pengambilan data burung dilakukan menggunakan metode point count (Bibby et al., 2000), menggunakan plot berbentuk lingkaran dengan diameter sebesar $50 \mathrm{~m}$. Jarak antar titik lebih dari 200 $\mathrm{m}$ dan bertujuan untuk memperkecil perhitungan ganda (Bibby et al., 1998). Pengambilan data dilakukan dengan mengobservasi burung di titik pengamatan secara langsung. Alat bantu yang digunakan adalah kamera, binokuler dan buku pengenalan burung Bird of Sumatera, Java, Kalimantan and Bali.

Data faktor lingkungan yang diambil adalah faktor fisika seperti suara, intensitas cahaya, suhu udara, kelembaban dan kecepatan angin dan faktor biologi seperti jumlah aktivitas manusia dan vegetasi. Pengukuran faktor fisika menggunakan alat pengukur seperti Sound Level Meter, luxmeter, termometer, hygrometer dan anemometer. Faktor biologis seperti aktivitas manusia dinyatakan dengan jumlah manusia yang hadir di lokasi penelitian. Data vegetasi dikumpulkan menggunakan metode petak ganda (Heddy, 2012). Di setiap lokasi, jumlah petak contoh vegetasi dibuat sebanyak dengan Point Count untuk pengamatan burung. Setiap petak dibagi menjadi empat area pengamatan untuk semai, pancang, tiang dan pohon. Pada tipe penutupan lahan pemukiman hanya dilakukan perhitungan jumlah dan jenis tumbuhan. 
Penghitungan jumlah dari jenis-jenis burung yang ada dengan melihat nilai kelimpahan (Pi) dan dominansi (Di) tiap-tiap spesies (Magurran, 1988) yaitu:

$$
\mathrm{Pi}=\frac{n i}{\mathrm{~N}} ; \quad \mathrm{Di}=\frac{n i}{\mathrm{~N}} \times 100 \%
$$

Keterangan:

$\mathrm{ni} \quad=$ Jumlah individu burung spesies-i

$\mathrm{N} \quad=$ Jumlah total individu seluruh jenis burung

Di $\quad=$ Indeks dominansi jenis ke-i

Keanekaragaman jenis diketahui menggunakan Indeks Shannon Wiener. Sedangkan kemerataan pada suatu lokasi dapat diketahui menggunakan Indeks Kemerataan Jenis (Ludwig dan Reynolds, 1988) :

$$
\mathrm{H}^{\prime}=-\sum \mathrm{Pi} \ln \mathrm{Pi} ; \quad \mathrm{E}=\mathrm{H}^{\prime} / \ln \mathrm{S}
$$

Keterangan:

$\mathrm{H}^{\prime} \quad=$ Indeks keanekaragaman Shannon-Wiener

$\mathrm{Pi} \quad=$ Proporsi nilai penting jenis ke-i

Ln = Logaritma natural

$\mathrm{E} \quad=$ Indeks Kemerataan Jenis

$\mathrm{S} \quad=$ Jumlah jenis yang ditemukan

Nilai tolak ukur indeks keanekaragaman yaitu:

$\mathrm{H}^{\prime}<1,0=$ Keanekaragaman rendah, miskin, produktivitas sangat rendah sebagai indikasi adanya tekanan yang berat dan ekosistem tidak stabil

$1,0<\mathrm{H}^{\prime}<3,322=$ Keanekaragaman sedang, produktivitas cukup, kondisi ekosistem cukup seimbang, tekanan ekologis sedang

$\mathrm{H}^{\prime}>3,322=$ Keanekaragaman tinggi, produktivitas tinggi, tahan terhadap tekanan ekologis

Nilai indeks kemerataan (E) berkisar antara 0-1. Semakin kecil nilai E atau mendekati nol, maka semakin tidak merata penyebaran organisme dalam komunitas tersebut yang di dominasi oleh jenis tertentu dan sebaliknya semakin besar nilai $\mathrm{E}$ atau mendekati satu, maka organisme dalam komunitas akan menyebar secara merata (Krebs, 1989).

Faktor lingkungan untuk suara, intensitas cahaya, suhu udara, kelembaban dan kecepatan angin dianalisis secara korelasi dan dihubungkan dengan jumlah keanekaragaman jenis burung. Analisis korelasi faktor lingkungan terhadap keanekaragaman burung di tiap tipe klasifikasi penutupan lahan menggunakan pendekatan statistik multivariate Analisis Komponen Utama (Principal Component Analysis/PCA). Software yang digunakan untuk analisis $P C A$ adalah PAST3 versi 1.0. Faktor lingkungan untuk aktivitas manusia dianalisis secara deskriptif dan dihubungkan dengan jmlah keanekaragaman jenis burung, sedangkan data vegetasi dianalisis menggunakan metode analisis vegetasi.

Hasil analisis vegetasi digunakan untuk menghitung Indeks Nilai Penting (INP) di setiap lokasi untuk mengetahui dominasi jenis pada lokasi pengamatan. INP dihitung berdasarkan jumlah seluruh nilai kerapatan relatif (KR), frekuensi relatif (FR) dan dominansi relatif (DR) untuk tingkat tiang dan 
pohon. Sedangkan untuk mengetahui INP pada tingkat semai dan pancang, dihitung dari nilai kerapatan relatif (KR) dan frekuensi relatif (Soerianegara \& Indrawan, 1988).

INP Tiang dan Pohon $=$ KR + FR + DR; $\quad$ INP Semai dan Pancang $=$ KR + FR

\section{HASIL DAN PEMBAHASAN}

Hasil pengamatan di Taman Wisata Alam Hutan Gambut Baning Sintang diperoleh 32 jenis burung yang mewakili 18 famili dan 5 ordo dengan jumlah individu sebanyak 989 dari seluruh jenis burung yang dijumpai (Tabel 1).

Tabel 1. Jumlah dan Jenis Burung di Kawasan Taman Wisata Alam Hutan Gambut Baning Sintang

\begin{tabular}{|c|c|c|c|c|}
\hline No. & Ordo & Famili & Spesies & Jumlah \\
\hline 1 & Acciptiriformes & Acciptiridae & Circus spilonotus & 2 \\
\hline \multirow[t]{2}{*}{2} & Apodiformes & Apodidae & Collocalia esculenta & 125 \\
\hline & & Hemiprocnidae & Hemiprocne comate & 2 \\
\hline \multirow[t]{2}{*}{3} & Cuculiformes & Cuculidae & Cacomantis merulinus & 3 \\
\hline & & & Centropus bengalensis & 4 \\
\hline \multirow[t]{4}{*}{4} & Columbiformes & Columbidae & Columba livia & 2 \\
\hline & & & Streptopelia bitorquata & 4 \\
\hline & & & Streptopelia chinensis & 18 \\
\hline & & & Treron vernans & 2 \\
\hline \multirow[t]{23}{*}{5} & Passeriformes & Campephagidae & Hemipus picatus & 19 \\
\hline & & Dicaeidae & Dicaeum everetti & 34 \\
\hline & & Dicruridae & Dicrurus annectans & 4 \\
\hline & & & Dicrurus paradiseus & 6 \\
\hline & & Hirundinidae & Hirundo rustica & 41 \\
\hline & & & Hirundo tahitica & 18 \\
\hline & & Laniidae & Lanius cristatus & 5 \\
\hline & & Muscicapidae & Ficedula mugimaki & 1 \\
\hline & & Nectariniidae & Anthreptes malacensis & 2 \\
\hline & & Ploceidae & Lonchura fuscans & 76 \\
\hline & & & Passer montanus & 365 \\
\hline & & Pycnonotidae & Hypsipetes flavala & 2 \\
\hline & & & Ixos malaccensis & 3 \\
\hline & & & Pycnonotus brunneus & 11 \\
\hline & & & Pycnonotus goiavier & 132 \\
\hline & & & Pycnonotus plumosus & 19 \\
\hline & & & Pycnonotus simplex & 15 \\
\hline & & Silviidae & Orthotomus ruficeps & 17 \\
\hline & & & Prinia flaviventris & 7 \\
\hline & & Sturnidae & Acridotheres tristis & 5 \\
\hline & & & Gracula religiosa & 4 \\
\hline & & Tiimalidae & Stachyris erythroptera & 25 \\
\hline & & Zosteropidae & Zosterops palpebrosus & 16 \\
\hline
\end{tabular}

Burung yang termasuk dalam ordo Passeriformes merupakan burung yang paling mendominasi dengan 13 famili dan 23 jenis. Menurut MacKinnon et al. (2010), ordo Passeriformes merupakan ordo burung dengan jumlah jenis paling besar yang mencakup lebih dari setengah dari seluruh spesies burung yang telah teridentifikasi. Alim et al., (2020) juga menyatakan bahwa ordo Passeriformes adalah ordo dengan jenis aves kosmopolit karena penyebaran habitatnya yang luas dan spesies paling banyak di antara ordo dari kelas Aves lainnya. Kawasan TWA Hutan Gambut Baning Sintang terdapat empat tipe 
penutupan lahan sehingga memiliki kondisi lingkungan yang beragam. Anggota ordo Passeriformes memiliki relung hidup yang luas sehingga mampu hidup di berbagai tipe habitat (Ericson et al., 2014).

Kelimpahan (Pi) dan dominansi (Di) burung di tiap tipe penutupan lahan memiliki nilai yang berbeda-beda (Tabel 2). Hasil pengamatan di tipe penutupan lahan hutan primer mendapatkan 17 jenis burung dan 126 individu. Stachyris erythroptera adalah jenis yang memiliki nilai kelimpahan (Pi) terbesar $(0,198413)$ dan burung berkategori dominan ( $\mathrm{Di}>5 \%$ ). Serasah atau daun kering di lantai hutan primer yang banyak menyebabkan nilai kelimpahan dan nilai dominasi $S$. erythroptera tinggi. Mansor et al. (2015) dalam hasil penelitiannya menemukan bahwa S. erythroptera lebih banyak berada di atas serasah daun untuk tempat mencari serangga. Jenis burung dengan nilai kelimpahan dan dominansi terendah di tipe penutupan lahan hutan primer adalah Ixos malaccensis dan Ficedula mugimaki $(\mathrm{Pi}=0,007937$; Di= 0,79\%). F. mugimaki merupakan burung pengunjung yang berasal dari timur Siberia dan timur laut Cina (West, 2002). F. mugimaki sering mengunjungi hutan dataran rendah dan pegunungan di seluruh Sumatera dan Kalimantan. Burung ini senang hinggap di dahan pohon-pohon besar (MacKinnon, 2010). Tipe penutupan lahan hutan primer di kawasan TWA Hutan Gambut Baning Sintang masih memiliki pohon-pohon besar yang sesuai untuk tempat bersarang dan mencari makan bagi burung pengunjung.

Jenis burung dengan nilai kelimpahan dan dominansi terendah lainnya di hutan primer adalah Ixos malaccensis. I. malaccensis merupakan salah satu burung pemakan buah (frugivora) yang mencari pakan di pucuk ranting pepohonan. Burung-burung ini sudah jarang terlihat di TWA Hutan Gambut Baning Sintang karena telah terjadi perusakan habitat di daerah hutan primer. Menurut Gregory (2000), perusakan habitat hutan seperti penebangan pohon-pohon besar akan membuat burung-burung penghuni kanopi atas jarang terlihat karena kehilangan tempat untuk membuat sarang maupun mencari makan.

Tabel 2. Nilai Kelimpahan (Pi) dan Dominansi (Di) Jenis Burung di Empat Tipe Penutupan Lahan Kawasan TWA Hutan Gambut Baning

\begin{tabular}{llcccccccc}
\hline \multirow{2}{*}{ No. } & \multirow{2}{*}{ Nama spesies } & \multicolumn{2}{c}{ Hutan Primer } & Hutan Sekunder & Semak Belukar & \multicolumn{2}{c}{ Pemukiman } \\
\cline { 2 - 10 } & $\mathbf{P i}$ & $\mathbf{D i}(\%)$ & $\mathbf{P i}$ & $\mathbf{D i}(\%)$ & $\mathbf{P i}$ & Di (\%) & Pi & Di (\%) \\
\hline 1 & Dicrurus paradiseus & 0,048 & 4,763 & - & - & - & - & - & - \\
2 & Stachyris erythroptera & $* 0,198$ & $* 19,841$ & - & - & - & - & - & - \\
3 & Hemipus picatus & 0,087 & 8,730 & 0,070 & 7,018 & - & - & - & - \\
4 & Circus spilonotus & 0,016 & 1,587 & - & - & - & - & - & - \\
5 & Hemiprocne comate & 0,016 & 1,587 & - & - & - & - & - & - \\
6 & Pycnonotus brunneus & 0,071 & 7,143 & 0,018 & 1,754 & - & - & - & - \\
7 & Pycnotus goiavier & 0,103 & 10,317 & $* 0,482$ & $* 48,256$ & 0,160 & 16,049 & 0,028 & 2,824 \\
8 & Hypsipetes flavala & 0,016 & 1,587 & - & - & - & - & - & - \\
9 & Pycnonotus simplex & 0,063 & 6,349 & 0,061 & 6,140 & - & - & - & - \\
10 & Collocalia esculenta & 0,040 & 3,968 & - & - & $* 0,247$ & $* 24,691$ & 0,094 & 9,412 \\
11 & Gracula religiosa & 0,032 & 3,175 & - & - & - & - & - & - \\
12 & Ixos malaccensis & $* * 0,008$ & $* * 0,794$ & 0,018 & 1,754 & - & - & - & - \\
13 & Zosterops palpebrosus & 0,048 & 4,762 & 0,088 & 8,772 & - & - & - & - \\
14 & Dicrurus annectans & 0,032 & 3,175 & - & - & - & - & - & - \\
\hline
\end{tabular}




\begin{tabular}{|c|c|c|c|c|c|c|c|c|c|}
\hline \multirow{2}{*}{ No. } & \multirow{2}{*}{ Nama spesies } & \multicolumn{2}{|c|}{ Hutan Primer } & \multicolumn{2}{|c|}{ Hutan Sekunder } & \multicolumn{2}{|c|}{ Semak Belukar } & \multicolumn{2}{|c|}{ Pemukiman } \\
\hline & & $\mathbf{P i}$ & Di (\%) & $\mathbf{P i}$ & Di (\%) & $\mathbf{P i}$ & Di (\%) & $\mathbf{P i}$ & Di (\%) \\
\hline 15 & Orthotomus ruficeps & 0,135 & 13,492 & - & - & - & - & - & - \\
\hline 16 & Dicaeum everetti & 0,079 & 7,937 & 0,149 & 14,912 & 0,022 & 2,160 & - & - \\
\hline 17 & Ficedula mugimaki & $* * 0,008$ & $* * 0,794$ & - & - & - & - & - & - \\
\hline 18 & Streptopelia bitorquata & - & - & 0,035 & 3,509 & - & - & - & - \\
\hline 19 & Treron vernans & - & - & 0,018 & 1,754 & - & - & - & - \\
\hline 20 & Pycnonotus plumosus & - & - & - & - & 0,059 & 5,864 & - & - \\
\hline 21 & Prinia flaviventris & - & - & - & - & 0,022 & 2,160 & - & - \\
\hline 22 & Lanius cristatus & - & - & - & - & 0,015 & 1,543 & - & - \\
\hline 23 & Lonchura fuscans & - & - & - & - & 0,235 & 23,457 & - & - \\
\hline 24 & Acridotheres tristis & - & - & - & - & 0,015 & 1,543 & - & - \\
\hline 25 & Cacomantis merulinus & - & - & - & - & 0,009 & 0,926 & - & - \\
\hline 26 & Centropus bengalensis & - & - & - & - & 0,012 & 1,235 & - & - \\
\hline 27 & Columba livia & - & - & - & - & - & - & $* * 0,005$ & $* * 0,471$ \\
\hline 28 & Hirundo rustica & - & - & 0,035 & 3,509 & 0,102 & 10,185 & 0,009 & 0,941 \\
\hline 29 & Anthreptes malacensis & - & - & $* * 0,009$ & $* * 0,877$ & $* * 0,003$ & $* * 0,309$ & - & - \\
\hline 30 & Streptopelia chinensis & - & - & 0,018 & 1,754 & 0,043 & 4,321 & $* * 0,005$ & $* * 0,471$ \\
\hline 31 & Hirundo tahitica & - & - & - & - & 0,037 & 3,704 & 0,014 & 1,412 \\
\hline 32 & Passer montanus & - & - & - & - & 0,019 & 1,852 & ${ }^{*} 0,845$ & $* 84,471$ \\
\hline
\end{tabular}

Keterangan: $\quad$ - : Tidak ditemukan, ${ }^{*}$ : Nilai tertinggi, ${ }^{* *}:$ Nilai terendah

Hasil pengamatan di tipe penutupan lahan hutan sekunder mendapatkan 12 jenis burung dan 114 individu. Burung dengan nilai kelimpahan dan nilai dominansi tertinggi adalah Pycnonotus goiavier ( $\mathrm{Pi}=$ 0,482456; Di= 48,25\%). Pycnonotus goiavier berasal dari famili Pycnonotidae yang sering berkelompok dan berbaur dengan burung-burung lainnya. Burung ini dapat ditemukan di segala jenis habitat, terkecuali hutan lebat, dari habitat mangrove sampai habitat terbuka, hutan sekunder, kebun bahkan daerah urban (Amit et al., 2015). Burung dengan nilai kelimpahan dan dominansi terendah adalah Anthreptes malacensis ( $\mathrm{Pi}=0,008772 ; \mathrm{Di}=0,88 \%$ ). Nilai kelimpahan dan dominansi $\mathrm{A}$. malacensis yang rendah karena burung tersebut beraktifitas sendiri atau berpasangan. Selain tidak berkelompok, burung ini juga bersifat teritorial dan agresif dalam menjaga wilayahnya (MacKinnon et al., 2010).

Hasil pengamatan di tipe penutupan lahan Semak Belukar mendapatkan 15 jenis burung dan 324 individu. Berdasarkan nilai kelimpahan (Pi) dan nilai dominansi (Di), Collocalia esculenta adalah burung dengan nilai tertinggi $(\mathrm{Pi}=0,246914 ; \mathrm{Di}=24,69 \%)$, C. esculenta berasal dari famili Apodidae yang terbang di semua tipe hutan dan lahan pertanian (MacKinnon, 2010). Pada titik 9 terdapat rumah walet sehingga menyebabkan populasi $C$. esculenta menjadi tinggi. Suara walet dari tape recorder memancing $C$. esculenta untuk terbang di sekitar rumah walet tersebut. Anthreptes malacensis juga ditemukan di lahan semak belukar namun memiliki nilai kelimpahan dan dominansi terendah $(\mathrm{Pi}=$ 0,003086; $\mathrm{Di}=0,31 \%$ ). Menurut MacKinnon et al. (2010), A. malacensis sulit ditemukan karena memiliki tingkah laku yang suka menyendiri atau berpasangan serta bersifat teritorial.

Hasil pengamatan di tipe penutupan lahan Pemukiman mendapatkan 7 jenis burung dan 425 individu. Berdasarkan nilai kelimpahan (Pi) dan nilai dominansi (Di), Passer montanus merupakan 
burung dengan nilai terbesar di daerah pemukiman ( $\mathrm{Pi}=0,844706 ; \mathrm{Di}=84,47 \%) . P$, montanus umumnya terdapat di daerah perkotaan maupun pedesaan (MacKinnon et al., 2010). Burung ini dapat berasosiasi dengan manusia, hidup berkelompok di sekitar rumah dan gudang serta mencari makan di tanah dan lahan pertanian. Burung dengan jumlah kelimpahan dan dominansi terendah di tipe penutupan lahan pemukiman adalah Columba livia dan Streptopelia chinensis $(\mathrm{Pi}=0,004706 ; \mathrm{Di}=0,004706)$. Menurut Baptista et al., (1997), C. livia termasuk burung kosmopolitan yang bisa berkontak dengan manusia dalam jarak dekat serta memiliki kemampuan untuk kembali ke kandang karena memiliki kemampuan navigasi melalui medan magnet, posisi matahari, suara atau bau sehingga bisa dipelihara tanpa dikurung dalam sangkar. S. chinensis juga ditemukan di tipe penutupan lahan hutan sekunder dan semak belukar. Burung ini berpasangan untuk mencari makanan di atas permukaan tanah (MacKinnon et al., 2010). Menurut Putra et al. (2014), S. chinensis mampu melakukan aktivitasnya dengan normal walaupun ada aktivitas manusia di dekatnya.

Nilai indeks keanekaragaman $\left(\mathrm{H}^{\prime}\right)$ dan indeks kemerataan (E) burung di masing-masing tipe penutupan lahan berbeda (Tabel 3). Nilai Indeks Keanekaragaman dan Kemerataan burung tertinggi ada di tipe penutupan lahan hutan primer $\left(\mathrm{H}^{\prime}=2,51 ; \mathrm{E}=0,89\right)$. Di lahan hutan primer ditemukan 15 jenis tumbuhan tingkat pohon. Jumlah ini lebih banyak dari tiga tipe tutupan lainnya. Hal ini sesuai dengan pernyataan Budi (2015), bahwa daerah yang keanekaragaman jenis tumbuhannya tinggi maka keanekaragaman jenis hewannya termasuk burung akan tinggi pula. Tews et al. (2004) juga menyatakan bahwa beragamnya jenis vegetasi yang terdapat pada suatu habitat mendukung ketersediaan pakan bagi burung sehingga semakin beragamnya vegetasi, maka burung akan mendapatkan lebih banyak pilihan untuk memilih jenis pakan.

Tabel 3. Nilai Indeks Keanekaragaman (H') dan Indeks Kemerataan (E) Tiap Tipe Penutupan Lahan di Kawasan TWA Hutan Gambut Baning Sintang

\begin{tabular}{clcc}
\hline No. & Tipe Penutupan Lahan & Indeks Keanekaragaman $\left(H^{\prime}\right)$ & Indeks Kemerataan (E) \\
\hline 1 & Hutan Primer & 2,51 & 0,89 \\
2 & Hutan Sekunder & 1,77 & 0,71 \\
3 & Semak Belukar & 2,12 & 0,78 \\
4 & Pemukiman & 0,62 & 0,32 \\
\hline
\end{tabular}

Rata-rata parameter suara pada tiap tipe penutupan lahan disajikan dalam Tabel 4. Terdapat nilai tertinggi dan nilai terendah untuk masing-masing faktor lingkungan pada tiap tipe penutupan lahan.

Tabel 4. Rata-rata Parameter Lingkungan Tiap Tipe Penutupan Lahan di Kawasan TWA Hutan Gambut Baning Sintang

\begin{tabular}{|c|c|c|c|c|c|c|c|c|c|c|c|}
\hline \multirow{3}{*}{ No. } & \multicolumn{3}{|c|}{ Penutupan } & \multirow{2}{*}{\multicolumn{2}{|c|}{ IC (Lux) }} & \multirow{2}{*}{\multicolumn{2}{|c|}{$\mathrm{SU}\left(\mathrm{C}^{\circ}\right)$}} & \multirow{2}{*}{\multicolumn{2}{|c|}{ K (\%) }} & \multirow{2}{*}{\multicolumn{2}{|c|}{$\mathrm{KA}(\mathrm{m} / \mathrm{s})$}} \\
\hline & Lahan & \multicolumn{2}{|c|}{$S(\mathrm{~dB})$} & & & & & & & & \\
\hline & & Pagi & Sore & Pagi & Sore & Pagi & Sore & Pagi & Sore & Pagi & Sore \\
\hline 1 & $\mathrm{HP}$ & $* * 47,37$ & $* * 46,53$ & $* * 41065$ & $* * 52023,3$ & $* * 24,2$ & $* * 31,6$ & *77 & $* 60$ & $* * 0,11$ & $* * 0,09$ \\
\hline 2 & HS & 47,61 & 46,61 & 45314,44 & 58321,11 & 24,5 & 32 & *77 & **59 & 0,14 & 0,16 \\
\hline 3 & SB & 49,54 & 48,65 & 81843,64 & *73187,5 & 29,28 & $* 32,28$ & 66 & **59 & 0,98 & $* 0,85$ \\
\hline 4 & $\mathrm{P}$ & $* 62,69$ & *59,8 & $*_{97608}, 89$ & 53927,78 & *32,02 & 31,86 & $* * 63$ & $* * 59$ & ${ }^{*} 1,02$ & 0,76 \\
\hline
\end{tabular}


Keterangan: HP: Hutan Primer; HS: Hutan Sekunder; SB: Semak Belukar; P: Pemukiman; S: Suara; IC: Intensitas Cahaya; SU: Suhu Udara; K: Kelembaban; KA: Kecepatan Angin; * : Nilai tertinggi, ${ }^{* *}$ : Nilai terendah

Aktivitas manusia turut mempengaruhi nilai keanekaragaman dan kemerataan burung di masing-masing tipe penutupan lahan. Daerah pemukiman merupakan daerah dengan aktivitas manusia terbanyak. Di daerah pemukiman terdapat 451 aktivitas manusia di pagi hari dan 399 aktivitas manusia di sore hari. Daerah pemukiman TWA Hutan Gambut Baning Sintang yang memiliki jalan utama menjadi penyebab ramainya kendaraan lalu-lalang sehingga menghasilkan tingkat suara terlalu keras dan banyaknya aktivitas. Tingkat atau intensitas suara yang terlalu keras berkaitan dengan pengaruh kebisingan terhadap burung. Selain aktivitas berkendara, aktivitas manusia lainnya seperti berjalan, berkumpul dan bermain dapat menjadi gangguan yang berbahaya terhadap burung. Alikodra (1997) menyatakan bahwa burung liar dengan sensitivitas tinggi lebih memilih tempat pembuatan sarang yang jauh dari keberadaan manusia karena takut diburu dan diambil telurnya (Tabel 5).

Tabel 5. Aktivitas Manusia di TWA Hutan Gambut Baning Sintang

\begin{tabular}{lcc}
\hline Tipe Penutupan Lahan & \multicolumn{2}{c}{ Jumlah Aktivitas } \\
\cline { 2 - 3 } & Pagi & Sore \\
\hline Hutan Primer & - & - \\
Hutan Sekunder & 1 & 19 \\
Semak Belukar & 8 & 399 \\
Pemukiman & 451 & \\
\hline
\end{tabular}

Keterangan: $\quad$ - : Tidak ada

Analisis vegetasi dilakukan pada tiap tipe penutupan lahan untuk mendapatkan Indeks Nilai Penting (INP) yang disajikan dalam Tabel 6, 7 dan 8. Pada Tabel 9 disajikan data jumlah dan jenis tumbuhan pada tipe penutupan lahan pemukiman.

Tabel 6. Nilai INP Tiap Tumbuhan di Tipe Penutupan Lahan Hutan Primer

\begin{tabular}{|c|c|c|c|c|c|c|c|c|c|}
\hline \multirow{2}{*}{ No. } & \multirow{2}{*}{ Nama Spesies } & \multicolumn{2}{|c|}{ Pohon } & \multicolumn{2}{|c|}{ Tiang } & \multicolumn{3}{|c|}{ Pancang } & \multirow{2}{*}{$\begin{array}{l}\text { Semai } \\
\text { INP (\%) }\end{array}$} \\
\hline & & Jumlah & INP (\%) & Jumlah & INP (\%) & Jumlah & INP (\%) & Jumlah & \\
\hline 1 & Dipterocarpus grandiflorus & 14 & 49,89 & 17 & 52,37 & 7 & 53,96 & 2 & 73,33 \\
\hline 2 & Gluta renghas & 10 & 37,48 & 13 & 39,33 & 3 & 30,70 & 1 & 36,67 \\
\hline 3 & Shorea sp. & 7 & 28,60 & - & - & 1 & 10,23 & - & - \\
\hline 4 & Dyospyros bantamensis & 3 & 15,31 & 5 & 19,12 & - & - & - & - \\
\hline 5 & Vatica $s p$ & 5 & 24,13 & 7 & 27,10 & - & - & - & - \\
\hline 6 & Eugenia sp. & 6 & 26,23 & 11 & 33,46 & 5 & 45,27 & 1 & 36,67 \\
\hline 7 & Litsea sp. & 3 & 15,14 & 5 & 19,31 & - & - & - & - \\
\hline 8 & Dactylocladus stenostachys & 2 & 10,30 & 4 & 14,20 & - & - & - & - \\
\hline 9 & Cratoxylum glaucum & 5 & 17,47 & 4 & 15,91 & - & - & - & - \\
\hline 10 & Dyera lowii & 2 & 10,25 & 4 & 14,55 & - & - & - & - \\
\hline 11 & Cratoxylum sp. & 2 & 10,02 & - & - & - & - & - & - \\
\hline 12 & Macaranga pruinosa & 2 & 10,13 & 4 & 17,88 & - & - & - & - \\
\hline 13 & Alstonia sp. & 1 & 5,18 & 3 & 11,84 & 3 & 24,80 & - & - \\
\hline 14 & Acacia mangium & 3 & 12,82 & 3 & 11,85 & 2 & 20,46 & 2 & 53,33 \\
\hline 15 & Vitex pinnata & 9 & 27,03 & 7 & 23,10 & 2 & 14,58 & - & - \\
\hline
\end{tabular}


Keterangan: -: Tidak ditemukan

Tabel 7. Nilai INP Tiap Tumbuhan di Tipe Penutupan Lahan Hutan Sekunder

\begin{tabular}{clcccccccc}
\hline & & \multicolumn{3}{c}{ Pohon } & \multicolumn{2}{c}{ Tiang } & \multicolumn{2}{c}{ Pancang } & \multicolumn{2}{c}{ Semai } \\
\cline { 3 - 9 } No. & \multicolumn{1}{c}{ Nama Spesies } & Jumlah & INP (\%) & Jumlah & INP (\%) & Jumlah & INP (\%) & Jumlah INP (\%) \\
\hline 1 & Cratoxylum sp. & 7 & 53,83 & 4 & 33,65 & 2 & 16,95 & - & - \\
2 & Eugenia sp. & 5 & 43,89 & 7 & 59,39 & 3 & 29,79 & - & - \\
3 & Dipterocarpus grandiflorus & 6 & 54,77 & 10 & 77,76 & 5 & 38,49 & - & - \\
4 & Dactylocladus stenostachys & 2 & 26,85 & 3 & 30,50 & - & - & - & - \\
5 & Alstonia sp. & 1 & 12,96 & - & - & - & - & - & - \\
6 & Acacia mangium & 4 & 35,95 & 4 & 36,58 & 4 & 34,14 & 1 & 34,17 \\
7 & Vatica sp. & 4 & 46,59 & - & - & - & - & - & - \\
8 & Gluta renghas & 3 & 25,17 & 2 & 24,54 & - & - & - & - \\
9 & Vitex pinnata & - & - & 1 & 13 & - & - & - & - \\
10 & Nephelium sp. & - & - & 1 & 11,12 & - & - & 1 & 34,17 \\
11 & Arthocarpus elasticus & - & - & 1 & 13,46 & 1 & 12,60 & - & - \\
12 & Dillenia eximia & - & - & & - & 7 & 55,43 & 3 & 83,22 \\
13 & Anacardium occidentale & - & - & - & - & 1 & 12,60 & 2 & 48,45 \\
\hline
\end{tabular}

Keterangan: $\quad$-: Tidak ditemukan

Tabel 8. Nilai INP Tiap Tumbuhan di Tipe Penutupan Lahan Semak Belukar

\begin{tabular}{clcccccccc}
\hline & & \multicolumn{3}{c}{ Pohon } & \multicolumn{2}{c}{ Tiang } & \multicolumn{2}{c}{ Pancang } & \multicolumn{2}{c}{ Semai } \\
\cline { 2 - 9 } No. & Nama Spesies & Jumlah & INP & Jumlah & INP & Jumlah & INP & Jumlah & INP \\
\hline 1 & Cratoxylum sp. & 7 & 102,33 & 10 & 97,63 & 3 & 37,36 & - & - \\
2 & Acacia mangium & 9 & 123,68 & 11 & 108,93 & 6 & 89,01 & - & - \\
3 & Alstonia sp. & 1 & 21,54 & - & - & - & - & - & - \\
4 & Shorea Pinanga & 2 & 31,61 & - & - & - & - & - & - \\
5 & Eugenia sp. & 1 & 20,84 & - & - & 1 & 21,98 & - & - \\
6 & Nephelium sp. & - & - & - & - & 1 & 21,98 & - & - \\
7 & Macaranga pruinosa & - & - & 9 & 93,44 & 2 & 29,67 & - & - \\
\hline
\end{tabular}

Keterangan: $\quad$-: Tidak ditemukan

Tabel 9. Jenis dan Jumlah Tumbuhan di Tipe Penutupan Lahan Pemukiman

\begin{tabular}{clcc}
\hline No. & \multicolumn{1}{c}{ Nama Spesies } & Nama Lokal & Jumlah \\
\hline 1 & Artocarpus integer & Cempedak & 3 \\
2 & Nephelium lappaceum & Rambutan & 2 \\
3 & Mangifera indica & Mangga & 3 \\
4 & Hibiscus rosa-sinensis & Kembang Sepatu & 3 \\
5 & Areca catechu & Pinang & 6 \\
6 & Psidium guajava & Jambu Biji & 1 \\
7 & Musa paradisiacal & Pisang & 4 \\
8 & Bambusa sp. & Bambu & 3 \\
9 & Syzygium aqueum & Jambu Air & 1 \\
\hline
\end{tabular}

Berdasarkan analisis vegetasi, nilai INP tertinggi terdapat pada tumbuhan Dipterocarpus grandiflorus dengan nilai INP sebesar 49,89\%. Gluta renghas dengan nilai INP sebesar 37,48\% dan Shorea 
sp. dengan nilai INP sebesar $28,60 \%$. INP menunjukkan ukuran penting dan peranan suatu tumbuhan dalam komunitas. Semakin besar nilai INP suatu tumbuhan, semakin besar peranan tumbuhan tersebut. Nilai INP berhubungan dengan kepadatan, frekuensi dan dominasi tumbuhan di suatu vegetasi. Tumbuhan yang memiliki nilai INP tinggi berarti memiliki tingkat kepentingan atau peranan jenis yang besar dalam suatu komunitas. Jenis-jenis yang memiliki nilai kepadatan, frekuensi dan dominasi yang tinggi pada suatu vegetasi akan memiliki nilai INP yang tinggi (Ahmad et al., 2016). Pada tipe penutupan lahan hutan primer yang memiliki nilai keanekaragaman paling tinggi di antara tiga tipe penutupan lahan lainnya, tumbuhan-tumbuhan bertajuk tinggi memiliki nilai INP paling besar. Nilai INP D. grandiflorus, G. renghas dan Shorea sp. yang tinggi menunjukkan peran tumbuhan tersebut di lahan hutan primer terutama bagi jenis-jenis burung di sana. Berdasarkan hasil penelitian Widodo \& Sulistyadi (2016), burung lebih sering menggunakan lapisan tajuk atas tumbuhan daripada tajuk tengah dan bawah. Tajuk atas pohon D. grandiflorus, G. renghas dan Shorea sp. sering digunakan burung untuk mencari pakan, bertengger atau beristirahat maupun membuat sarang.

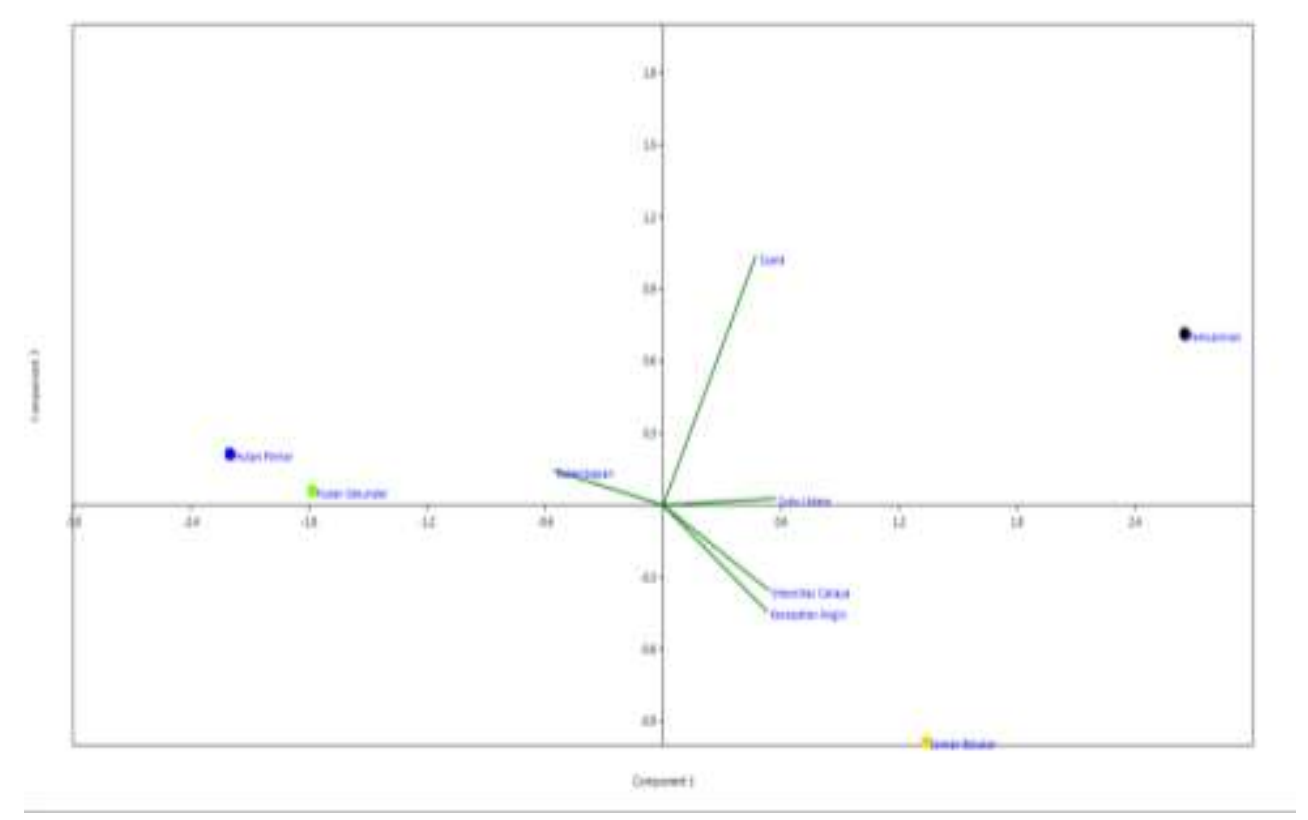

Gambar 2. Grafik Sebaran Variabel Faktor Lingkungan Terhadap Tiap Tipe Penutupan Lahan

Berdasarkan analisis PCA pada nilai scores tiap tipe penutupan lahan (Gambar 2), hutan primer dan hutan sekunder berada di posisi yang sama yakni di kuadran II. Hal tersebut menunjukkan bahwa kedua tipe tutupan lahan memiliki keadaan lingkungan yang hampir sama. Faktor lingkungan yang paling berpengaruh di hutan primer dan hutan sekunder adalah kelembaban. Nilai kelembaban pada factor loadings PC 1 adalah -0,46716, paling tinggi dan berarah negatif, sama seperti nilai scores di variabel hutan primer dan hutan sekunder. Masih adanya tajuk yang menutupi tanah di lahan hutan primer dan hutan sekunder menghalangi sinar matahari ke permukaan tanah. Selain itu dengan proses transpirasi, tanaman menyerap panas dan mengeluarkan uap air (Lakitan, 1997) sehingga kelembaban hutan primer dan hutan sekunder menjadi tinggi. Sementara itu di lahan semak belukar, faktor lingkungan yang 
paling mempengaruhi berdasarkan analisis PCA adalah intensitas cahaya dan kecepatan angin. Pada PC 2, nilai factor loadings intensitas cahaya dan kecepatan angin berada di arah negatif dan paling besar (intensitas cahaya $=-0,29742$; kecepatan angin $=-0,3713$ ), sesuai dengan nilai scores variabel semak belukar. Daerah semak belukar yang terbuka membuat cahaya matahari menyinari langsung ke permukaan tanah. Jumlah pohon yang sedikit di daerah semak belukar membuat pergerakan angin tidak terhambat sehingga nilai kecepatan angin menjadi tinggi. Di lahan pemukiman, faktor lingkungan yang berpengaruh adalah suara dan suhu udara. Banyaknya aktivitas manusia seperti berkendara menyebabkan terjadinya polusi udara sehingga mengganggu burung-burung yang bersifat sensitif (Melles et al., 2003).

\section{SIMPULAN}

Indeks keanekaragaman dan kemerataan tertinggi berada di tipe penutupan lahan hutan primer dan termasuk kategori keanekaragaman sedang, sedangkan terendah berada di tipe penutupan lahan pemukiman dan termasuk kategori keanekaragaman rendah. Nilai INP tertinggi pada tipe penutupan lahan hutan primer di semua tingkat adalah D. grandiflorus. Pada tipe penutupan lahan hutan sekunder, nilai INP tertinggi di tingkat pohon dan tiang adalah $D$. grandiflorus, sedangkan di tingkat pancang dan semai adalah $D$. eximia. Pada tipe penupupan lahan semak belukar, nilai INP tertinggi di semua tingkat adalah $A$. mangium. Pada tipe penutupan lahan pemukiman, $A$. catechu adalah jenis tumbuhan terbanyak yang ditemukan. Berdasarkan analisis PCA, kelembapan merupakan faktor lingkungan yang paling berpengaruh di tipe penutupan lahan hutan primer yang memiliki indeks keanekaragaman tertinggi dan suara merupakan faktor lingkungan yang paling berpengaruh di tipe penutupan lahan pemukiman yang memiliki indeks keanekaragaman terendah.

\section{DAFTAR PUSTAKA}

Ahmad, H., Roini, C., \& Ahsan, S. 2016. Analisis Struktur Vegetasi pada Habitat Kupu-kupu Papilio Ulysses di Pulau Kasiruta. Jurnal Bioedukasi, 4(2), 517-527

Alikodra, H.S. 1990. Pengelolaan Satwa Liar Volume II. Bogor: PAU Ilmu Hayat IPB.

Alikodra, H.S. 1997. Teknik Pengelolaan Satwa Liar Dalam Rangka Mempertahankan Keanekaragaman Hayati Indonesia. Bogor: Institut Pertanian Bogor.

Alim, S., Eddy, S., \& Mutiara, D. 2020. Karakteristik dan Deskripsi Ordo Passeriformes di Jalan Amri Yahya Jakabaring Palembang Sumatera Selatan. Jurnal Indobiosains, 2(2), 36-42

Amit, B., Tuen, A.A., Haron, K., Harun, M.H.,\& Kamarudin, N. 2015. The Diet of Yellow VentedBulbul (Pycnonotus goiavier) in Oil Palm Agro-Ecosystems. Journal of Oil Palm Research, 27(4), $417-$ 424

Baptista, L.F., Trail, P.W.,\& Horblit, H.M. 1997. Handbook of The Birds of The World Volume 4. Barcelona: Lynx Edicions.

Bibby, C., Jones, M.,\& Marsden, S. 1998. Expedition Field Techniques: Bird Surveys. London: Geography Outdoors.

Bibby, C., Jones, M.,\& Marsden, S. 2000. Survei Burung. Bogor: SMKG Mardi Yuana.

Budi, N.S. 2015. Kelimpahan dan Keanekaragaman Burung di Taman Laiwangi Wanggameti, Sumba Timur, Nusa Tenggara Timur. Skripsi. Universitas Islam Nusantara Sunan Kalijaga, Yogyakarta.

Ericson, P.G.P., Klopfsein, S., Irestedt, M., Nguyen, J.M.T.,\& Nylander, A.A. 2014. Dating The Diversification of The Major Lineages of Passeriformes (Aves). BMC Evolutionary Biology, 14(8), 115. 
Ghifari, B., Hadi, M., \& Tarwotjo, U. 2016. Keanekaragaman dan Kelimpahan Jenis Burung Pada Taman Kota Semarang. Jurnal Biologi, 5(2), 24-31

Gregory, S.M. 2000. Nomenclature of the Hypsipetes bulbuls (Pycnonotidae). Forktail, 16, 164-166.

Heddy, S. 2012. Metode Analisis Vegetasi dan Komunitas. Jakarta: Rajawali Pers.

Krebs, J.R. 1989. Ecology. The Experimental Analysis of Distribution and Abundance. Third Edition. New York: Harper and Row Distribution.

Kurniawati, H. 2012. Perencanaan Lanskap Kawasan Ekowisata Gambut Baning di Kota Sintang Kalimantan Barat. Tesis. Institut Pertanian Bogor, Bogor.

Kuswanda, W. 2007. Pengaruh Komposisi Tumbuhan Terhadap Populasi Burung di Taman Nasional Batang Gadis, Sumatera Utara. Jurnal Penelitian Hutan dan Konservasi Alam, 7(2), 193-213.

Laiolo, P.E., Caprio\& Rolando, A. 2003. Effects of Logging and Non-native Tree Proliferation on The Birds Overwintering in The Upland Forest of North-Western Italy. Forest Ecology and Management, $179,441-454$.

Lakitan, B. 1997. Dasar-dasar Klimatologi. Jakarta: Raja Grafindo Persada.

Ludwig, J.A. \& Reynold, J.F. 1988. Statistical Ecology, A Primer on Method on Competing. New York: Jhon Willey and Sons.

Mackinnon, J., Phillipps, K.,\& Balen, B.V. 2010. Burung-Burung di Sumatera, Jawa, Bali dan Kalimantan. Bogor: LIPI-Burung Indonesia.

Magurran, A.E. 1988. Ecological Diversity and Its Measurement. USA: Chapman and Hall.

Mansor, M.S., Ramli, R. \& Sah, S.A.M. 2015. 'The Foraging Tactics of Chesnut-winged Babbler (Stachyris erythroptera) and Abbott's Babbler (Malacocincla abbotti) in Lowland Rainforest Malaysia'. Sains Malaysiana, 44(5), hal. 687-69

Melles, S., Glenn, S.,\& Marti, K. 2003. Urban Bird Diversity and Landscape Complexity: Speciesenvironment Associations along A Multiscale Habitat Gradient. Conservervation Ecology, 7(5), 5-26.

Moen, A.N. 1973. Wildlife Ecology. San Fransisco: WH Freemen dan Company .

Putra, G.W., Harianto, S.P.,\& Nurcahyani, N. 2014. Perilaku Harian Burung Tekukur (Streptopelia chinensis) di Lapangan Tenis Uiversitas Lampung. Jurnal Sylva Lestari, 2(3), 93-100.

Soerianegara, I. \& Indrawan, A. 1982. Ekologi Hutan Indonesia. Bogor: Departemen Manajemen Hutan Fakultas Kehutanan Institusi Pertanian Bogor.

Tews, J., Brose, U., Grimm, V., Tielborger, K., Wichmann, M.C., Schwager, M.,\& Jeltsch, F. 2004. Animal Species Diversity Driven by habitat Heterogeneity/Diversity: The Importance of Keystone Structures. Journal of Biogeography, 31, 79-92.

Thompson, I.D., Hogan, H.A.,\& Montevecchi, W.A. 1999. Avian Communities of Mature Balsam Fir Forests in Newfoundland: Age-Dependence and Implications for Timber Harvesting. Condor. 101, 311-323.

Utaminingrum, H.I.P. \& Sulistyadi, E. 2010. Kajian Hubungan Tutupan Vegetasi dan Sebaran Burung di Pulau Moti, Ternante, Maluku Utara. Jurnal Biologi Indonesia, 6(3), 443-458

Welsh, D.A. 1987. The Influence of Forest Harvesting on Mixed Coniferous-Deciduous Boreal Bird Communities in Ontario. Acta Oceologica, 7, 247-252.

West, G.C. 2002. A Birder's Guide to Alaska (ABA Birdfinding Guide). Alaska: American Birding Association.

Widodo, W.\& Sulystiadi, E. 2016. Pola Distribusi dan Dinamika Komunitas Burung di Kawasan "Cibinong Science Center". Jurnal Biologi Indonesia, 12(1), 145-158. 